\title{
Effects of bacterial inoculation on the fermentation characteristics and aerobic stability of ensiled whole plant soybeans (Glycine max (L.) Merr.)
}

\author{
B.D. Nkosi ${ }^{1,3 \#}$, R. Meeske ${ }^{2}$, T. Langa ${ }^{1}$, M.D. Motiang ${ }^{1}$, S. Modiba $^{1}$, T.F. Mutavhatsindi ${ }^{1}$, \\ I.M.M. Malebana ${ }^{1}$ \& I.B. Groenewald ${ }^{3}$ \\ ${ }^{1}$ Division for Animal Nutrition: Animal Production Institute, P/Bag x 2, Irene, 0062, South Africa \\ ${ }^{2}$ Directorate: Animal Sciences, Department of Agriculture Western Cape, Outeniqua Research Farm, \\ P.O. Box 249, George, 6530, South Africa \\ ${ }^{3}$ Centre for Sustainable Agriculture, University of the Free State, P.O. Box 339, Bloemfontein, 9300, South Africa
}

(Received 14 July 2014; Accepted 8 February 2016; First published online 11 May 2016)

\begin{abstract}
Copyright resides with the authors in terms of the Creative Commons Attribution 2.5 South African Licence.
See: http://creativecommons.org/licenses/by/2.5/za

Condition of use: The user may copy, distribute, transmit and adapt the work, but must recognise the authors and the South African Journal of Animal Science.
\end{abstract}

\begin{abstract}
The effect of bacterial inoculation on the fermentation and aerobic stability of two ensiled whole plant soybean (WPSB) cultivars was determined in a $2 \times 2$ factorial design. Two WPSB cultivars, Link LF6466 and Pannar $522 \mathrm{RR}$, were harvested at their R6 growth stage, chopped to $25 \mathrm{~mm}$ and ensiled in $1.5 \mathrm{~L}$ anaerobic jars. The chopped forages were treated with or without the bacterial inoculant Lalsil Dry (LD) and treatments were as follows: i) Pan control (soybean cv Pannar 522 RR with no additive); ii) Link control (soybean cv Link LF 6466 with no additive); iii) Pan LD (soybean cv Pannar 522 RR treated with LD); and iv) Link LD (soybean cv Link LF 6466 treated with LD). Jars were opened on days 3, 7, 10, 21 and 90 to determine pH. Samples of day 0 and day 90 were used to determine chemical composition and fermentation characteristics. In addition, samples of day 90 were subjected to an aerobic stability test in which they were exposed to air for five days, and $\mathrm{CO}_{2}, \mathrm{pH}$, hours for temperature to rise above $2^{\circ} \mathrm{C}$, yeasts and moulds were determined. Pannar cultivar had higher contents of dry matter (DM), crude protein (CP), gross energy (GE) and ether extract (EE) compared with the Link cultivar at pre-ensiling. However, Link cultivar had higher content of water-soluble carbohydrates (WSC) compared with Pannar. Inoculation with LD reduced silage DM, CP and fibre contents, and increased silage $\mathrm{pH}$ compared with the control. Inoculation increased silage acetic and propionic acids, but had a lower content of lactic acid (LA) and DM recovery compared with the control. When compared with the control, silage aerobic stability was improved with LD inoculation, as indicated by reduced $\mathrm{CO}_{2}$ production, and yeast and mould populations, and increased number of hours for stability after aerobic exposure. It was concluded that LD inoculant reduced silage fermentation and preservation, but improved aerobic stability of silage. Further work is needed to determine the effects of soybean silage on growth performance and production response of ruminants.
\end{abstract}

Keywords: Cultivars, forages, inoculants, legumes, nutrients, silage, soybean

\# Corresponding author: dnkosi@arc.agric.za

\section{Introduction}

The shortage of quality feeds and their high costs are the most important obstacles towards achieving profitable livestock production in South Africa, especially under smallholder farming systems (Nkosi et al., 2011). Protein supplements, such as oil cakes (e.g. soybean oilcake) and urea, are used mainly in animal diets but are considered a limiting factor under smallholder farming conditions. This is because of the costs involved in purchasing these protein sources and the risk of improper use of urea by these farmers. In addition, South African law (Act 36, 1947) prohibited the use of protein sources of animal origin, and alternative sources of affordable plant origin should be considered.

Soybean (Glycine $\max (\mathrm{L})$ Merr.) is a highly productive summer forage legume of high quality, suitable for ruminant production operations, which normally depend on the declining quality of pastures. This forage is used in livestock diets in the form of oil cake, grain and hay in many commercial operations in South Africa. However, South Africa is a major importer of soybean oil cake, and imports of close to 1 million tons will be required by 2019 to supplement the shortfall in local production (BFAP, 2010).

Soybean is grown primarily for grain and oil production worldwide. However, adverse weather conditions may cause reduced seed yields and quality, forcing soybean producers to seek alternative uses 
for the crops (Coffey et al., 1995). As a result, interest in producing new high-yielding soybean varieties for use as forage rather than grain crops has increased in many parts of the world (Nayigihugu et al., 2002). According to Vargas-Bello-Perez et al. (2008), forage soybean cultivars are usually taller and later maturing than typical oilseed cultivars. To have enough feed to sustain ruminant production during winter months or drought, forage soybeans could be ensiled for this purpose.

Mustafa \& Seguin (2003) reported that well-preserved silages can be produced from forage-typed soybean cultivars, but this forage has its own limitations for ensiling. These include its WSC content, relatively high buffering capacity and moisture which make it difficult to ensile it successfully without additives. Lima et al. (2010) reported that soybean silage had the worst quality (highest $\mathrm{pH}$, ammonia- $\mathrm{N}$ and butyric acid content) of all silages evaluated. However, several studies have found that the addition of lactic acid bacteria (LAB) inoculants (Xu et al., 2011), molasses (Zhang et al., 2013) and cereal grains (Lima et al., 2010) before ensiling improved the preservation of silage from leguminous forages. In addition, some studies (Mustafa et al., 2007; Vargas-Bello-Perez et al., 2008) have shown that good-quality soybean silage could be produced when the forage was wilted before ensiling.

Although the fermentation quality of soybean silage was improved with the addition of sugarcane molasses and homofermentative LAB inoculants in some studies (Coffey et al., 1995; Tobia et al., 2008; Lima et al., 2010), the aerobic stability of the silage might be impaired by these additives, since low acetic acid levels were produced. In addition, forage soybean cultivars may differ in nutritive value and fermentation quality when ensiled (Coffey et al., 1995; Mustafa et al., 2007; Touno et al., 2014). Therefore, the present study was conducted to determine the ensilability of two forage soybean cultivars produced in South Africa and to determine the effects of adding a heterofermentative bacterial inoculant on the fermentation and aerobic stability of ensiled forage soybean cultivars. The hypothesis tested was that the addition of the heterofermentative bacterial inoculant, Lalsil Dry (LD), to forage soybean will improve both the fermentation and aerobic stability of the ensiled forages.

\section{Materials and Methods}

Two whole crop forage soybean (Glycine max) cultivars, Pannar 522 RR (Pannar Seed Pty Ltd, Hildesheim Farm, Greytown, KwaZulu-Natal, South Africa) and Link LF6466 (Link Seed Pty Ltd, Greytown, KwaZulu-Natal, South Africa), were grown on a sandy loam soil at $38-50 \mathrm{~cm}$ row spacing in October 2013. These cultivars were harvested in March 2014 at the R6 (full-size green beans) stage and chopped to a theoretical cut length of $25 \mathrm{~mm}$ with a John Deere 6810 (John Deere Co., Moline, III.) forage harvester. The chopped forages were left untreated (control) or treated with LD inoculant (Lallemand Animal Nutrition, Blagnac Cedex, France), which contains Pediococcus acidilactici (CNCM MA 18/5M), Lactobacillus buchneri (NCIMB 40788) and enzymes (cellulose and hemicellulose). To ensure that the required application of inoculant per fresh forage was obtained before ensiling, the suspensions were plated immediately on de Man, Rogosa and Sharpe agar (Oxoid CM0361, Unipath, Basingstoke, UK) and analysed for LAB populations following the International Dairy Federation (IDF) standard (1991) procedure. The LD inoculant was used by mixing $0.5 \mathrm{~g}$ with $100 \mathrm{~mL}$ water to treat $100 \mathrm{~kg}$ forage. This was done to meet a targeted inoculation rate of $3.5 \times 10^{5}$ colony forming units (CFU)/g of fresh forage. To ensure the same amount of moisture as in the treated forage, the control (100 kg fresh forage) was sprayed with $100 \mathrm{~mL}$ water just prior to compaction in silos.

The study was conducted in a $2 \times 2$ factorial design in which two ensiling treatments (control and LD) were evaluated on two soybean cultivars, soybean cv Link LF 6466 (denoted as Link) and soybean cV Pannar 522 RR (denoted as Pan). The treatments were arranged as follows: i) Pan control (soybean cV Pannar 522 RR with no additive); ii) Link control (soybean cv Link LF 6466 with no additive), iii) Pan LD (soybean cv Pannar 522 RR treated with LD); and iv) Link LD (soybean cv Link LF 6466 treated with LD). The chopped material was thoroughly mixed before being pack into $1.5 \mathrm{~L}$ anaerobic jars (J. Weck, GmBHu. Co., Wehr-Oflingen, Germany). Each jar was filled with approximately $850 \mathrm{~g}$ (wet weight) chopped forage without headspace, and a packing density of $567 \mathrm{~kg} \mathrm{DM} / \mathrm{m}^{3}$ was obtained. Jars were kept at room temperature for 90 days. Triplicate samples per treatment were collected on day 0 (pre-ensiled materials) and three jars per treatment were then opened on days 3, 7, 21 and 90 post ensiling to determine the $\mathrm{pH}$. In addition, samples collected on days 0 and 90 were used to determine nutritive values and fermentation profiles.

Samples of day 90 were subjected to an aerobic stability test in which $500 \mathrm{~g}$ sample from each jar was packed loosely in an open plastic jar, which was covered with two layers of cheesecloth and kept at $28^{\circ} \mathrm{C}$. Thermocouples (T-type copper constantan, 20-gauge wire) were placed in the geometric centre of the silage mass in each jar and also in the room where the jars were stored to record temperature. Room temperature and the temperature in each jar were simultaneously recorded at one-hour intervals using a CR7X data 
logger (Campbell Scientific, Logan, Utah) for five days. Carbon dioxide production (Ashbell, et al., 1991), pH and yeasts and moulds were determined after the five-day exposure following the IDF procedure (1990).

A representative $40 \mathrm{~g}$ silage sample was taken from each jar to determine the fermentation characteristics. The $40 \mathrm{~g}$ silage sample $(\mathrm{n}=3)$ was mixed with $360 \mathrm{~mL}$ distilled water in a stomacher bag, homogenized for four minutes, and $\mathrm{pH}$ was immediately determined with a $\mathrm{pH}$ meter (Thermo Orion Model 525, Thermo Fisher Scientific, Waltham, Mass., USA). It was then filtered through Whatman No. 54 filter paper (GIC Scientific, Midrand, Gauteng, South Africa). The extract was used to determine pH, water soluble carbohydrates (WSC), volatile fatty acids (VFAs), lactic acid (LA) and ammonia-N. The WSC were determined by the phenol-sulphuric acid method of Dubois et al. (1956). Lactic acid was determined by the modified colorimetric method of Pryce (1969). The VFAs were determined with a Varian 3300 FID Detector gas chromatograph (Varian Associates, Inc., Palo Alto, Calif., USA) by the procedure of Suzuki \& Lund (1980). Ammonia N was determined by distillation using Buchi 342 apparatus and Metrohm 655 Dosimat with E526 titrator, according to AOAC (ID 941.04, 1990).

The dry matter (DM) of pre-ensiled mixtures and of silages was determined by drying the samples at $60{ }^{\circ} \mathrm{C}$ until a constant mass was achieved, and was corrected for loss of volatiles using the equation of Weissbach \& Strubelt (2008). Dry matter recovery was calculated using weights of compacted jars before and after the 90-day ensiling period, and the DM contents. After drying, the samples were ground through a 1-mm screen (Wiley mill, Standard Model 3, Arthur H. Thomas Co., Philadelphia, Pa.) for crude protein (CP), gross energy (GE), ether extract (EE), neutral detergent fibre (aNDF), acid detergent fibre (ADF) and acid detergent lignin (ADL) analyses. The CP was determined according to the procedure of AOAC (1990, ID 968.06), while GE was determined with an adiabatic bomb calorimeter (IKA C7000, Staufen, Germany). The aNDF, ADF and the ADL were determined according to the procedures of Van Soest et al. (1991). The aNDF concentration was determined using heat stable $\alpha$-amylase (Sigma-Aldrich Co. LTD., Gillingham, UK, no. A1278) with sodium sulphite, and the ADF concentration was determined using the Fibretec System equipment (Tecator Ltd., Thornbury, Bristol, UK). Separate samples were used for ADF and aNDF analysis and both included residual ash.

For microbiological analyses, forage or silage $(10 \mathrm{~g})$ was added to $90 \mathrm{~mL}$ sterile $70 \mathrm{mM}$ potassium phosphate buffer $(\mathrm{pH}=7.0)$ and agitated for $60 \mathrm{sec}$ at $260 \mathrm{rpm}$ in a high-power laboratory blender (Blendfast ${ }^{\mathrm{TM}}$, Waring Commercial, 314 Ella T. Grasso Ave., Torrington, Connecticut, USA). The suspension was serially diluted $\left(10^{-2}\right.$ to $\left.10^{-7}\right)$, and $100-\mu \mathrm{L}$ aliquots of each dilution were spread in triplicate onto semiselective MRS agar (MRS, Oxoid, Basingstoke, UK) to enumerate LAB (Lactobacilli), onto nutrient agar (Oxoid, Basingstoke, UK) to enumerate total bacteria (TB), and onto potato dextrose agar (PDA, SigmaAldrich Pty Ltd, South Africa) to enumerate yeasts and moulds. Lactobacilli MRS agar and nutrient agar (NA) plates were incubated at $37^{\circ} \mathrm{C}$ for $24-48 \mathrm{~h}$, while PDA plates were incubated at $25^{\circ} \mathrm{C}$ for $72 \mathrm{~h}$. Colonies were counted from plates containing a minimum of 30 colonies and a maximum of 300 .

The experiment was carried out as a completely randomized design (CRD) replicated three times. The treatment design was a $2 \times 2$ factorial with factors cultivar (Pannar and Link) and ensiling treatments (control and LD). Data on microbial populations were expressed in $\log ^{10} \mathrm{CFU} / \mathrm{g}$ of forage or silage prior to statistical analysis. Data were subjected to an appropriate analysis of variance (ANOVA), and analysed using GenStat $\circledR$ (2011). Means of significant effects were compared using Student's t-LSD (least significant difference) at a 5\% significance level (Snedecor \& Cochran, 1980).

The model fitted:

$$
Y_{i j k}=\mu+T_{i}+\alpha_{j}+T_{i} \alpha_{j}+\varepsilon_{i j k}
$$

where $Y_{i j k}$ is the individual observations of the $i^{\text {th }}$ treatment,

$j^{\text {th }}$ cultivar and $k^{\text {th }}$ replicate, $\mu$ is the general mean,

$T_{i}$ and $\alpha_{j}$ are the main effect and the interaction is $T_{i} \alpha_{j}$ with error $\varepsilon_{i j k}$ as the random variation or experimental error.

\section{Results}

Data on the chemical composition of pre-ensiled soybean cultivars are shown in Table 1. The Pannar cultivar had higher $(P<0.05) \mathrm{DM}, \mathrm{CP}, \mathrm{GE}$ and EE compared with the Link cultivar. However, the Link cultivar had higher $(P<0.05)$ WSC content compared with the Pannar cultivar. Inoculation increased $(P<0.05)$ the LAB population compared with the control (Table 2).

Data on the fermentation characteristics and aerobic stability of soybean forages after $90 \mathrm{~d}$ of ensiling are shown in Table 3. Inoculation reduced $(P<0.05)$ silage DM, CP, fibre (aNDF, ADF and ADL) contents and increased silage $\mathrm{pH}$ compared with the control. Inoculation increased $(P<0.05)$ silage acetic acid $(\mathrm{AA})$ and propionic acid $(P A)$ contents, but had lower $(P<0.05)$ lactic acid $(\mathrm{LA})$ content and DM recovery compared with the control. However, silage aerobic stability was improved $(P<0.05)$ with LD inoculation. 
There was a gradual decline in $\mathrm{pH}$ between day 0 and day 3 in soybean silages, except for the Pannar control, which declined between days 3 and 7 (Figure 1).

Table 1 Chemical composition of soybean cultivars at pre-ensiling $(n=3)$

\begin{tabular}{|c|c|c|c|c|}
\hline \multirow{2}{*}{ Parameter } & \multicolumn{2}{|c|}{ Cultivar } & \multirow{2}{*}{ SEM } & \multirow{2}{*}{$P$} \\
\hline & Pannar 522 RR & Link LF6466 & & \\
\hline $\mathrm{DM}$ g/kg & $333.3^{\mathrm{a}}$ & $268.0^{b}$ & 0.943 & 0.001 \\
\hline CP g/kg DM & $176.7^{\mathrm{a}}$ & $169.7^{b}$ & 0.596 & 0.001 \\
\hline GE MJ/kg DM & $18.21^{\mathrm{a}}$ & $17.07^{\mathrm{b}}$ & 0.049 & 0.001 \\
\hline EE g/kg DM & $67.09^{\mathrm{a}}$ & $44.2^{\mathrm{b}}$ & 1.60 & 0.001 \\
\hline $\begin{array}{l}\text { aNDF g/kg } \\
\text { DM }\end{array}$ & $404.4^{b}$ & $453.1^{\mathrm{a}}$ & 1.93 & 0.001 \\
\hline ADF g/kg DM & 304.4 & 312.9 & 2.38 & 0.064 \\
\hline ADL g/kg DM & 64.60 & 67.50 & 1.384 & 0.213 \\
\hline WSC g/kg DM & $64.3^{\mathrm{b}}$ & $72.0^{\mathrm{a}}$ & 1.88 & 0.001 \\
\hline $\mathrm{pH}$ & 7.03 & 7.04 & 0.033 & 0.946 \\
\hline
\end{tabular}

${ }^{a-b}$ Means in the same row with different superscripts differ significantly $(P<0.05)$.

DM: dry matter; CP: crude protein; GE: gross energy; EE: ether extract; aNDF: amylase treated neutral detergent fibre; ADF: acid detergent fibre; ADL: acid detergent lignin; WSC: water-soluble carbohydrates.

\section{Discussions}

The main goal in silage making is to maintain the original quality of the preserved crop as much as possible (Wilkinson \& Davies, 2012). As a result, additives have been used to direct the fermentation process towards the production of LA as the main fermentation product. When silage DM content is less than $250 \mathrm{~g} / \mathrm{kg}$, conditions for clostridial activity are favourable, resulting in high losses and silage of low nutritional value (Wilkinson, 2005). In this study, the DM content of freshly chopped Pannar cultivar was $333 \mathrm{~g} \mathrm{DM} / \mathrm{kg}$, while that of Link cultivar was $268 \mathrm{~g} \mathrm{DM} / \mathrm{kg}$ (Table 1), suitable for ensiling. This is agreement with Coffey et al. (1995), who reported differences in DM content between Bay soybean forage and Stafford soybean forage at pre-ensiling. Mustafa \& Seguin (2003) reported $264 \mathrm{~g} \mathrm{DM} / \mathrm{kg}$ in wilted forage soybean before ensiling, comparable with Link forage soybean before ensiling in the current study. However, the DM in forage soybean cultivars before ensiling was higher than $248 \mathrm{~g} \mathrm{DM} / \mathrm{kg}$ reported by Tobia et al. (2008) in unwilted forage soybean at ensiling. Wilting soybean forage before ensiling resulted in silage that contained $>478 \mathrm{~g} \mathrm{DM} / \mathrm{kg}$ in some studies (Mustafa et al., 2007; Vargas-Bello-Perez et al., 2008), which is higher than those of the present study. Inoculating soybean forage cultivars with LD at pre-ensiling resulted in an increased $(P<0.05)$ population of LAB compared with the control (Table 2), which is consistent with other studies (Reich \& Kung, 2010), in which LAB inoculation was applied during ensiling of forage. The higher DM content of the Pan control compared with the Link control and the lower DM of LD inoculated forages were supported by the higher $(P<0.05)$ DM recoveries in the control compared with the LD treatment. The DM losses associated with the LD treated soybean silages could be explained by the biochemistry of the heterofermentative pathway, as outlined in the review by Wilkinson \& Davies (2012). The present study corroborated that of Martinez-Fernandez et al. (2010), who reported high DM losses when L. buchneri was applied to direct-cut forages of faba beans at ensiling. This effect is reduced in wilted forages, probably because the higher DM content in wilted forages reduces the overall activity of L. buchneri (MartinezFernandez et al., 2010), and the soybean forages in the present study were not wilted before ensiling

The CP and WSC contents in forages are the two most important compositional factors that affect the nutritional quality of cereal silages (Hargreaves et al., 2009). The LD treatment reduced the CP content of soybean silage compared with control silages (Table 3). This was reflected by the increase in ammonia- $\mathrm{N}$ content in the LD treated silages. This was not consistent to other studies in which LB inoculation improved the CP content of silage (Rooke et al., 1988; Gordon, 1989; Nkosi \& Meeske, 2010). However, the present study agrees with that of Zhang et al. (2013), who reported reduced CP content with LD inoculation in Urtica cannabina silage. Other studies (Mustafa \& Seguin, 2003; Lima et al., 2013; Touno et al., 2014) have 
recorded CP values in soybean silage that are higher than in the soybean silage of the present study, which might be attributed to the different soybean forage cultivars used amongst these studies.

Table 2 Mean lactic acid bacteria (LAB) and yeast populations in forage soybean at pre-ensiling $(n=3)$

\begin{tabular}{lccccccc}
\hline \multirow{2}{*}{ Microbes $\left(\log _{10}\right.$ cfu/g) } & \multicolumn{5}{c}{ Treatments } & \multirow{2}{*}{ SEM } & $\boldsymbol{P}$ \\
\cline { 2 - 5 } & Pan Control & Pan LD & Link Control & Link LD & & \\
\hline \multirow{2}{*}{ LAB } & $3.46^{\mathrm{b}}$ & $7.9^{\mathrm{a}}$ & $3.81^{\mathrm{b}}$ & $8.2^{\mathrm{a}}$ & 2.64 & 0.005 \\
Yeasts & 3.5 & 3.7 & 3.4 & 3.2 & 1.85 & 0.108 \\
\hline
\end{tabular}

Cultivars: Pan: Pannar 522 RR; Link: Link LF6466. LD: bacterial inoculant, Lalsil Dry.

${ }^{a-b}$ Means in the same row with different superscripts differ significantly $(P<0.05)$.

Inoculation did not affect EE contents in soybean silages of the present study (Table 3). In contrast, the inoculation of soybean silage with $L$. brevis reduced EE content compared with a control (Tobia et al., 2008). However, the effect of cultivar was significant, and the Pannar cultivar had higher $(P<0.05) \mathrm{EE}$ content compared with the Link cultivar. This might be because of higher EE content in the Pannar cultivar before ensiling. The EE content in the Pannar soybean silage was higher than $42 \mathrm{~g} \mathrm{EE} / \mathrm{kg}$ DM reported in the literature (Tobia et al., 2008; Dias et al. 2010; Lima et al., 2013). The relatively high EE content of soybean silage is an important feed parameter since it represents a high energy contribution to balanced animal feeds. However, the energy content in soybean silage of the present study did not differ $(P>0.05)$ among treatments and cultivars.

Concentrations of NDF in silages that are lower than the original herbage reflect the breakdown of hemicellulose during ensiling, which provides additional substrate for the fermentation. Hemicellulose also can be degraded through hydrolysis by organic acids produced during fermentation or can be applied with silage additives (McDonald et al., 1991). However, it has been reported that the effects of LAB inoculants on fibre degradation are not consistent because $L A B$ cannot effectively use fibre as an energy source to produce lactic acid (Muck, 2010). Faber et al. (1989) attributed the lack of response with LAB inoculation to a lower environmental temperature that inhibited hemicellulose degradation. However, LD inoculation reduced $(P<0.05)$ the fibre fractions (aNDF, ADF and ADL) of soybean silage compared with the control. This might be because LD inoculant contains enzymes that may be capable of degrading fibre. In contrast, inoculation did not affect the ADF or aNDF content in maize silage compared with the control silage (Reich \& Kung, 2010). Further, Xu et al. (2011) reported improved in vitro CP digestibility of milk vetch silage treated with LD inoculant compared with a control.

Silage $\mathrm{pH}$ is one of the main criteria that reflect the extent of fermentation and quality of ensiled forages. It is well known that legume forages are rich in proteins, of which $10 \%-20 \%$ of the buffering effect of plant constituents on $\mathrm{pH}$ is attributed to proteins (McDonald et al., 1991). Legumes, with their low watersoluble carbohydrate content and a higher buffering capacity, generally reach a terminal $\mathrm{pH}$ of about 4.5 . A rapid decline of $\mathrm{pH}$ during the early stages of ensiling is required to ensure good silage quality (McDonald et al., 1991). The decline in $\mathrm{pH}$ of ensiled forages can be attributed to the fermentation of WSC by LAB (McDonald et al., 1991). The final pH of soybean silage was reduced to 5.1 for the LD inoculated silages and 4.5 and 4.4 for the Pan and Link control silages, respectively (Table 3). The higher pH on the inoculated silages may be attributed to less efficient utilization of the limited amount of WSC present in the whole crop soybean prior to ensiling. However, the $\mathrm{pH}$ was not low enough for efficient preservation, because it should range between 3.8 and 4.2 for well-preserved silage (Kung \& Shaver, 2001), but was typical of that of soybean silage reported in the literature (e.g. Coffey et al., 1995, Nayigihugu et al., 2002, Mustafa \& Seguin, 2003). The LD inoculation increased $(P<0.05)$ silage $\mathrm{pH}$ compared with the control. It is well known that inoculation of LB to forages at ensiling may result in increased silage $\mathrm{pH}$ compared with untreated silages (Driehuis et al., 2001, Kristensen et al., 2010). In contrast, LB inoculation did not influence the pH in maize silage (Reich \& Kung, 2010), but reduced that of potato hash silage compared with control (Nkosi \& Meeske, 2010). However, inoculation of a homofermentative $L A B$ to forage soybean at ensiling reduced silage $\mathrm{pH}$ compared with a control (Coffey et al., 1995, Tobia et al., 2008). The pH of LD inoculated soybean silages in this study was lower than 6, recorded in Urtica cannabina (legume forage) treated with LD inoculant after 60 days of ensiling (Zhang et al., 2013). 
Table 3 Mean (SEM) chemical composition, fermentation characteristics and aerobic stability of whole plant soybean silage after 90 days of ensiling $(n=3)$

\begin{tabular}{|c|c|c|c|c|c|c|c|c|}
\hline \multirow[b]{2}{*}{ Parameter } & \multicolumn{4}{|c|}{ Treatments } & \multirow[b]{2}{*}{ SEM } & \multicolumn{3}{|c|}{ Significant effect $(P)$} \\
\hline & $\begin{array}{c}\text { Pan } \\
\text { Control }\end{array}$ & Pan LD & $\begin{array}{c}\text { Link } \\
\text { Control }\end{array}$ & Link LD & & TRT & Cult & $\begin{array}{c}\text { TRT } x \\
\text { Cult }\end{array}$ \\
\hline \multicolumn{9}{|l|}{ Chemical composition } \\
\hline $\mathrm{DM} \mathrm{g} / \mathrm{kg}$ & $318.0^{\mathrm{a}}$ & $254.7^{\mathrm{C}}$ & $303.7^{\mathrm{b}}$ & $228.3^{d}$ & 1.500 & 0.001 & 0.001 & 0.004 \\
\hline $\mathrm{CP}$ g/kg DM & $151.7^{\mathrm{b}}$ & $149.0^{c}$ & $162.5^{\mathrm{a}}$ & $142.1^{\mathrm{C}}$ & 1.154 & 0.017 & 0.001 & 0.001 \\
\hline GE MJ/kg DM & 18.1 & 18.4 & 18.4 & 18.1 & 0.121 & 0.915 & 0.790 & 0.057 \\
\hline EE g/kg DM & $63.9^{\mathrm{a}}$ & $64.7^{\mathrm{a}}$ & $43.3^{b}$ & $47.1^{\mathrm{b}}$ & 0.367 & 0.061 & 0.011 & 0.081 \\
\hline aNDF g/kg DM & $452.3^{b}$ & $390.2^{d}$ & $474.0^{a}$ & $398.5^{c}$ & 0.628 & 0.001 & 0.001 & 0.001 \\
\hline ADF $\mathrm{g} / \mathrm{kg} \mathrm{DM}$ & $347.3^{b}$ & $314.0^{\mathrm{C}}$ & $393.4^{\mathrm{a}}$ & $314.7^{c}$ & 0.600 & 0.001 & 0.001 & 0.001 \\
\hline ADL g/kg DM & $68.2^{\mathrm{b}}$ & $57.7^{d}$ & $75.1^{\mathrm{a}}$ & $62.0^{c}$ & 0.252 & 0.001 & 0.001 & 0.001 \\
\hline \multicolumn{9}{|c|}{ Fermentation characteristics } \\
\hline WSC g/kg DM & $2.07^{\mathrm{c}}$ & $2.39^{\mathrm{bc}}$ & $2.66^{b}$ & $6.47^{\mathrm{a}}$ & 0.100 & 0.001 & 0.001 & 0.001 \\
\hline $\mathrm{pH}$ & $4.5^{\mathrm{b}}$ & $5.1^{\mathrm{a}}$ & $4.4^{\mathrm{b}}$ & $5.1^{\mathrm{a}}$ & 0.063 & 0.001 & 0.466 & 0.579 \\
\hline LA g/kg DM & $41.6^{b}$ & $31.9^{d}$ & $54.8^{\mathrm{a}}$ & $38.2^{c}$ & 0.193 & 0.001 & 0.001 & 0.001 \\
\hline AA g/kg DM & $42.8^{c}$ & $52.7^{b}$ & $41.0^{c}$ & $61.2^{\mathrm{a}}$ & 1.092 & 0.001 & 0.001 & 0.001 \\
\hline PA g/kg DM & $3.2^{d}$ & $28.6^{b}$ & $6.9^{c}$ & $37.1^{\mathrm{a}}$ & 0.373 & 0.001 & 0.001 & 0.002 \\
\hline $\mathrm{NH}_{3}-\mathrm{N} \mathrm{g} / \mathrm{TN}$ & $54.8^{d}$ & $78.2^{b}$ & $74.7^{\mathrm{c}}$ & $99.4^{\mathrm{a}}$ & 1.391 & 0.001 & 0.001 & 0.743 \\
\hline DM recovery g/kg & $958^{\mathrm{a}}$ & $918^{\mathrm{b}}$ & $966^{\mathrm{a}}$ & $915^{\mathrm{b}}$ & 11.2 & 0.002 & 0.092 & 0.161 \\
\hline \multicolumn{9}{|c|}{ Aerobic stability after 5 days of exposure } \\
\hline $\mathrm{CO}_{2} \mathrm{~g} / \mathrm{kg} \mathrm{DM}$ & $16.4^{\mathrm{b}}$ & $7.9^{d}$ & $21.6^{\mathrm{a}}$ & $12.9^{\mathrm{c}}$ & 0.296 & 0.001 & 0.001 & 0.877 \\
\hline${ }^{1}$ Hours & $61.8^{b}$ & $72.8^{\mathrm{a}}$ & $55.6^{b}$ & $75.8^{\mathrm{a}}$ & 0.920 & 0.001 & 0.232 & 0.069 \\
\hline $\begin{array}{l}\text { Yeasts and } \\
\text { moulds cfu/g } \log _{10}\end{array}$ & $4.5^{\mathrm{a}}$ & $3.3^{\mathrm{b}}$ & $4.5^{\mathrm{a}}$ & $3.3^{\mathrm{b}}$ & 1.91 & 0.001 & 0.089 & 0.052 \\
\hline
\end{tabular}

Cultivars: Pan: Pannar 522 RR; Link: Link LF6466. LD: bacterial inoculant, Lalsil Dry.

${ }^{a-d}$ Means in the same row with different superscripts differ significantly $(P<0.05)$.

DM: dry matter; CP: crude protein; GE: gross energy; EE: ether extract; aNDF: amylase treated neutral detergent fibre; ADF: acid detergent fibre; ADL: acid detergent lignin; WSC: water-soluble carbohydrates; LA: lactic acid; AA: acetic acid; PA: propionic acid; $\mathrm{NH}_{3}-\mathrm{N} \mathrm{g} / \mathrm{TN}$ : ammonia- $\mathrm{N}$ g/total $\mathrm{N}$; $\mathrm{CO}_{2}$ : carbon dioxide;

${ }^{1}$ Hours: time for a $2{ }^{\circ} \mathrm{C}$ increase above room temperature.

Trt: treatment; Cult: cultivar; Trt x Cult: treatment x cultivar interactions.

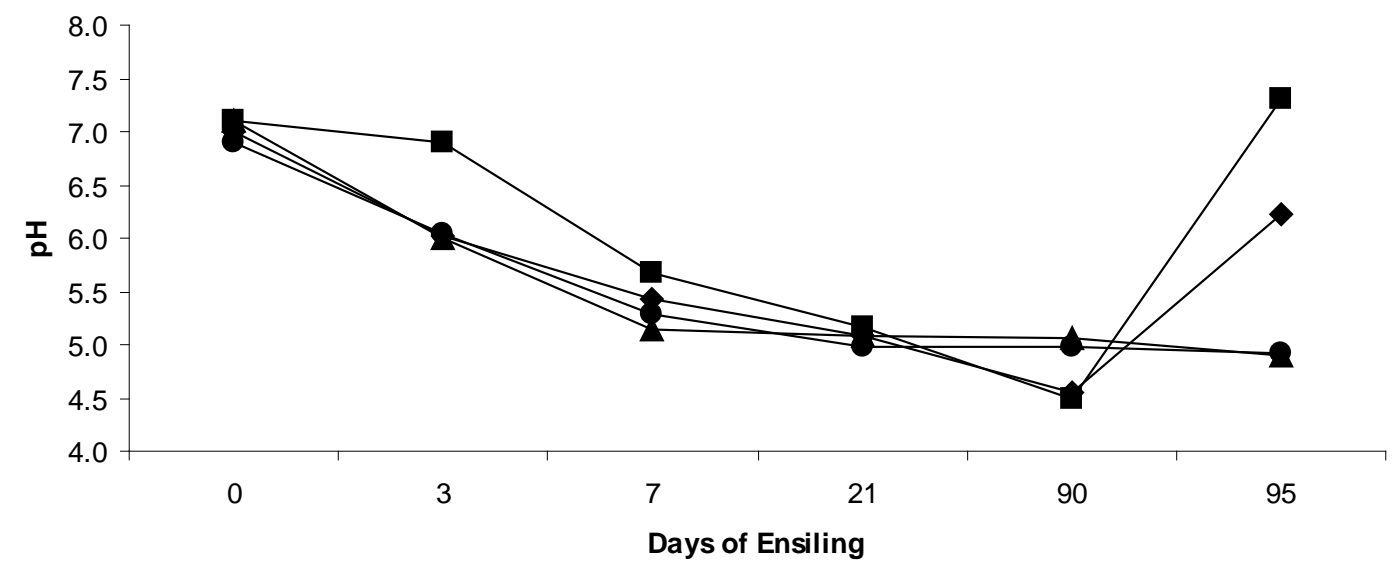

Figure 1 Effects of treatments (Pan control $(\bullet)$, Link control (४), Pan LD $(\mathbf{\Delta})$, Link LD $(\bullet))$ on pH and aerobic stability (days 90 - 95) of whole crop soybean silage.

Cultivars: Pan: Pannar 522 RR; Link: Link LF6466. LD: bacterial inoculant, Lalsil Dry. 
Water-soluble carbohydrates are regarded as essential substrates for growth of LAB for proper fermentation (McDonald et al., 1991), and low levels may restrict LAB growth. Lunden-Pettersson\& Lindgren (1990) recommended an amount of $60-70 \mathrm{~g} \mathrm{WSC} / \mathrm{kg}$ DM for achieving well-preserved silage. The soybean cultivars had WSC content within this range (Table 1), with highest recorded in the Pannar cultivar (70 $\mathrm{g}$ WSC/kg DM). The WSC in forage soybean cultivars before ensiling was higher than 30 and $35 \mathrm{~g} \mathrm{WSC/kg}$ DM recorded in other studies (Mustafa \& Seguin, 2003; Mustafa et al., 2007). It has been reported that the initial WSC concentration in forages varies widely with genotype, maturity at harvest and climatic conditions such as crop heat units and frost (Addah et al., 2011), which might explain differences in WSC content in the soybean cultivars in this study compared with those recorded in the literature. Lower $(P<0.05)$ residual WSC was obtained in the control treatment compared with LD treated silage. The level of residual WSC, however, was reduced in all treatments, indicating that most WSC were utilized during fermentation. Higher residual WSC in silage may be beneficial to ruminants, since it supplies energy to animals. However, residual WSC in silage may serve as substrate for aerobic microbes during the feeding-out phase (Weinberg et al., 1993).

Lactic acid is the strongest of all silage acids, and its presence would decrease the pH more effectively than other VFAs. This can be achieved by the use of silage LAB inoculants to increase the number of homofermentative $L A B$ in the ensiled forage. However, this depends on the amount and type of sugars present in the crop at ensiling. When the LAB were using hexose sugars, the fermentation becomes homofermentative, while the utilization of pentose sugars results in a hetero-fermentative fermentation (Wilkinson \& Davies, 2012). The lower levels of LA in the inoculated forage soybean compared with the control are in contrast to Zhang et al. (2013), who reported increased LA production in LD-treated Urtica cannabina silage compared with control. Xu et al. (2011) reported the same phenomenon in LD-treated milk vetch (Astragalus adsurgens) compared with control treatment, inconsistent with the current study. However, this study is consistent with those of Ranjit et al. (2002) and Kristensen et al. (2010, who reported reduced LA production in maize silage treated with $L$. buchneri compared with control silage.

A review of 11 studies on the use of inoculants containing $L$. buchneri during the ensiling of forages indicated that L. buchneri increased the levels of AA and ammonia-N in silages by $270 \%$ and $113 \%$, respectively (Wilkinson \& Davies, 2012). It is also reported that LA is converted into AA with $L$. buchneri inoculation, and thus higher AA compared with LA can be obtained (Oude Elferink et al., 2001). The LD inoculant increased the contents of acetic and propionic acids compared with the control (Table 3), and is in line with the general findings of the effects of inoculation with L. buchneri (Kleinschmidt \& Kung, 2006; Kristensen et al., 2010; Nkosi et al., 2012).

Ammonia- $\mathrm{N}$ in silage reflects the degree of protein degradation. Well-preserved silages should contain less than $100 \mathrm{~g} \mathrm{NH}_{3}-\mathrm{N} / \mathrm{kg}$ total nitrogen (TN) (McDonald et al., 2002). The effects of LAB inoculants on ammonia-N reduction in silage compared with untreated silage have been reported (Rooke et al., 1988; Gordon, 1989; Nkosi \& Meeske, 2010). Generally, inoculation with L. buchneri has not increased ammonia content of maize silages (Kleinschmidt \& Kung, 2006; Mari et al., 2009), although an increase in ammonia was observed in grass silage (Driehuis et al., 2001). The effects of treatments on the ammonia- $\mathrm{N}$ content in soybean silages in the present study followed a similar pattern to the CP contents. Inoculation of soybean forages with LD before ensiling did not restrict $(P<0.05)$ proteolysis, as indicated by its higher ammonia-N content compared with untreated (Table 3), consistent with Martinez-Fernandez et al. (2010). The increase in ammonia- $\mathrm{N}$ concentration in the LD treated silages might be due to relatively higher $\mathrm{pH}$ caused by high metabolic activity of the LB bacterium (Driehuis et al., 2001). However, silages of the present study had an ammonia-N content that was within acceptable levels $\left(<100 \mathrm{~g} \mathrm{NH}_{3}-\mathrm{N} / \mathrm{kg} \mathrm{TN}\right)$ for well-preserved silages (McDonald et al., 2002).

The aerobic deterioration of silage may increase the risk of proliferation of potential pathogenic or undesirable micro-organisms, thus affecting the performance of animals fed the silage. $\mathrm{Higher} \mathrm{CO}_{2}$ production in silage indicates the activity of yeasts and moulds, which cause a rise in temperature and reduce the quality of silage (Woolford, 1990; Ashbell et al., 1991). Weinberg et al. (1993) concluded that residual WSC and LA were both substrates for yeast and mould growth, and that AA inhibited the growth of these organisms. The aerobic stability of the control soybean silage was poor, based on the intensive $\mathrm{CO}_{2}$ production, increases in $\mathrm{pH}$, and a rise in temperature and yeast and mould populations, compared with the treated silages (Table 3). This is in agreement with Szucs \& Avasi (2005) and Szucs et al. (2011), who reported improved aerobic stability of lucerne silage with LD inoculant. In contrast, the aerobic stability of triticale-faba silage was not improved by LB inoculation (Martinez-Fernandez et al., 2010). Barbosa et al. (2011) recorded a rise in $\mathrm{pH}$ to 8.8 from soybean silage after seven days of aerobic exposure, consistent with that of the Link control in the present study. Increases in acetic and propionic acids in silages treated with L. buchneri accompanied improvements in the aerobic stability of barley silage (Kung et al., 1999). The LD inoculated soybean silages of the present study had higher acetic and propionic acid and improved aerobic stability compared with the untreated silages. Ranjit et al. (2002) added L. buchneri to maize silage 
and the control silage heated after 18 hours, while the treated silages remained stable for longer periods. The untreated soybean silages heated after 55 and 62 hours for Link and Pannar cultivars, while the LD treated silages heated after 73 hours, respectively. The $\mathrm{pH}$ of the untreated silages went above 6 after 5 days' aerobic exposure (Figure 1), indications of poor aerobic stability compared with LD inoculated silages. The rapid increase in $\mathrm{pH}$ of the control silage compared with the LD inoculated silages was probably caused by high yeast populations in the control silage. Yeasts are known to initiate aerobic deterioration of silage (McDonald et al, 1991; Driehuis et al., 2001) and addition of L. buchneri to silage impaired the activity of yeasts (Driehuis et al., 2001). Numbers of yeasts were extremely low or not detectable in silages treated with L. buchneri compared with the control maize silage in some studies (Kristensen et al., 2010; Reich \& Kung, 2010). The inoculation of $L$. buchneri during the ensiling of forages is often criticized because of the increase in silage $\mathrm{pH}, \mathrm{AA}$ and losses in DM and energy (Reich \& Kung, 2010; Wilkinson \& Davies, 2012). However, if aerobic stability is improved, the loss of nutrients incurred by the addition of $L$. buchneri may be moderate in comparison with what might have been lost at feed-out through aerobic deterioration (Nkosi \& Meeske, 2010).

\section{Conclusions}

Good quality silage can be produced from forage soybean Pannar and Link cultivars. The inoculation of forage soybean cultivars with LD at ensiling reduced silage fermentation quality, but improved the aerobic stability of the silage. The application of hetero-fermentative inoculants on forages that contain limited amounts of WSC may be discouraged. Further work to determine effects of soybean silage on nutrient utilization and growth performance of ruminants is needed to determine whether the silage is a viable alternative to conventional forages.

\section{Acknowledgements}

The authors would like to acknowledge C. Ngwane (ARC-Biometrics) for help with the statistical analyses of the data. The Small Ruminant Nutrition Research team of the API is also acknowledged for its role in the production of silage for this project.

\section{Authors' contributions}

BDN and RM were in charge of project design and writing of the manuscript. BDN, TL, MDM, TFM, SM and IMMM were in charge of project implementation. All co-authors participated in results, statistics and interpretation of the study.

\section{Conflict of interest declaration}

We wish to confirm that there are no known conflict of interest associated with the publication of this manuscript and there has been no significant financial support for this work that could have influenced its outcome. We also confirm that this manuscript has been read and approved by all authors and that the order of authors listed in the manuscript has been approved by all of us.

\section{References}

ACT 36, 1947. Fertilizer, Farm feeds, Agricultural remedies and Stock Remedies Act. National Department of Agriculture, Pretoria, South Africa.

Addah, W., Baah, J., Groenewegen, P., Okine, E.K. \& McAllister, T.A., 2011. Comparison of the fermentation characteristics, aerobic stability and nutritive value of barley and corn silages ensiled with or without a mixed bacterial inoculant. Can. J. Anim. Sci. 91, 133-146.

AOAC, 1990. Official methods of analysis (15th ed.). Association of Official Analytical Chemists, Washington DC, USA.

Ashbell, G., Weinberg, Z.G., Azriel, A., Hen, Y. \& Horev, B., 1991. A simple system to study the aerobic deterioration of silages. Can. Agric. Eng. 33, 391-393.

Barbosa, L.A., Rezende, A.V., Rabelo, C.H.S., Rabelo, F.H.S. \& Nogueira, D.A., 2011. Aerobic stability of corn and soybean silage mixed at different ratios. ARS Veterinaria 27, 255-262.

BFAP, 2010. Bureau for Food and Agricultural Policy. The South African Agricultural Baseline. www.bfap.co.za

Coffey, K.P., Granade, G.V. \& Moyer, J.L., 1995. Nutrient content of silages made from whole-plant soybeans. The Prof. Anim. Sci. 11, 74-80.

Dias, F.J., Jobim, C.C., Filho, J.L.S., Bumbieris Jr., V.H., Poppi, E.C. \& Santello, G.A., 2010. Chemical composition and dry matter total losses of soybean plant silage. Acta Scient. 32, 19-26.

Driehuis, F., Oude Elferink, S.J.W.H. \& Van Wikselaar, P.G., 2001. Fermentation characteristics and aerobic stability of grass silage inoculated with Lactobacillus buchneri, with or without homofermentative lactic acid bacteria. Grass Forage Sci. 56, 330-343.

Dubois, M., Giles, K.A., Hamilton, J.K., Rebes, P.A. \& Smith, F., 1956. Colorimetric method for determination of sugars and related substances. Anal. Chem. 28, 350-356.

Faber, D.A., Linn, J.G. \& Otterby, D.E., 1989. Effect of a bacterial inoculant on the fermentation of high moisture shelled and ear corn. J. Dairy Sci. 72, 1234-1242. 
Genstat, 2011. GenStat for Windows (14th ed.) (Payne, R.W., Murray, D.A. \& Harding, S.A.). VSN International, Hemel Hempstead, UK.

Gordon, H.K., 1989. An evaluation through lactating cows of a bacterial inoculant as an additive for grass silage. Grass Forage Sci. 44, 169-179.

Hargreaves, A., Hill, J. \& Leaver, J.D., 2009. Effect of stage of growth on the chemical composition, nutritive value and ensilability of whole-crop barley. Anim. Feed Sci. Technol. 152, 50-61.

IDF, 1990. International Standard 94B. Milk and milk products - enumeration of yeasts and moulds. Colony count technique at $25^{\circ} \mathrm{C}$. International Dairy Federation, Brussels, Belgium.

Kleinschmit, D.H. \& Kung Jr., L., 2006. The effects of Lactobacillus buchneri 40788 and Pediococcus pentosaceus R1094 on the fermentation of corn silage. J. Dairy Sci. 89, 3999-4004.

Kristensen, N.B., Sloth, K.H., Hojberg, O., Spliid, N.H., Jensen, C. \& Thogersen, R., 2010. Effects of microbial inoculants on corn silage fermentation, microbial contents, aerobic stability and milk production under field conditions. J. Dairy Sci. 93, 3764-3774.

Kung Jr., L. \& Shaver, R., 2001. Interpretation and use of silage fermentation analysis reports. University of Wisconsin, Madison, WI, USA. Focus on Forage 3 (13), 1-5.

Kung Jr., L., Ranjit, N. K., Robinson, J.R. \& Charley, R.C., 1999. The effect of Lactobacillus buchneri on the fermentation and aerobic stability of barley silage. The XII ${ }^{\text {th }}$ International Silage Conference. Uppsala, Sweden. pp. 272-273.

Lima, R., Lourenco, M., Diaz, R.F., Castro, A. \& Fievez, V., 2010. Effect of combined ensiling of sorghum and soybean with or without molasses and Lactobacilli on silage quality and in vitro rumen fermentation. Anim. Feed Sci. Technol. 155, 122-131.

Lima, J.A., Gavioli, I.L.C., Barbosa, C.M.P., Berndt, A., Gimenes, F.M.A. \& Paz, C.C.P., 2013. Soybean silage and sugarcane tops silage on lamb performance. Ciencia Rural 43, 1478-1484.

Lunden-Pettersson, P.K. \& Lindgren, S., 1990. The influence of the carbohydrate fraction and additives on silage quality. Grass Forage Sci. 45, 223-233.

Mari, L.J., Schmidt, R.J., Nussio, L.G., Hallada, C.M. \& Kung Jr., L., 2009. An evaluation of the effectiveness of Lactobacillus buchneri 40788 to alter fermentation and improve the aerobic stability of corn silage in farm silos. J. Dairy Sci. 92, 1174-1176.

Martinez-Fernandez, A., Soldado, A., Vicente, F., Martinez, A. \& de la Roza-Delgado, B., 2010. Wilting and inoculation of Lactobacillus buchneri on intercropped triticale-faba silage: effects on nutritive, fermentation and aerobic stability characteristics. Agric. Food Sci. 19, 302-312.

McDonald, P., Henderson, A.R. \& Heron, S.J.E., 1991. The Biochemistry of Silage. Chalcombe Publications, Marlow, Buckinghamshire, UK. pp. 109.

McDonald, P., Edwards, R.A., Greenhalgh, J.F.D. \& Morgan, C.A., 2002. Animal Nutrition. 6th Edition. Longman $\S `$ Scientific and Technical.

Muck, R.E., 2010. Silage additives and management issues. Proceedings of Idaho Alfalfa Forage Conference, Best Western Burley Inn, Burley, Idaho, USA. 16-17 February. pp. 49-55.

Mustafa, A.F. \& Seguin, P., 2003. Characteristics and in situ degradability of whole crop faba bean, pea, and soybean silages. Can. J. Anim. Sci. 83, 793-799.

Mustafa, A.F., Garica, J.C.F., Seguin, P. \& Marois-Mainguy, O., 2007. Chemical composition, ensiling characteristics and ruminal degradability of forage soybean cultivars. Can. J. Anim. Sci. 87, 623-629.

Nayigihugu, V., Kellog, D.W., Longer, P.D.E., Johnson, Z.B., Anschutz, K.A. \& Devine, T.E., 2002. Performance and ensiling characteristics of tall-growing soybean lines used for silage: Case study. The Prof. Anim. Sci. 18, 85-89.

Nkosi, B.D. \& Meeske, R., 2010. Effects of ensiling a totally mixed potato hash ration with or without a heterofermentative bacterial inoculant on silage fermentation quality, aerobic stability, growth performance and digestibility in lambs. Anim. Feed Sci. Technol. 161, 38-48.

Nkosi, B.D., Leeuw, K.J., Langa, T. \& Thomas, R.S., 2011. Effects of different dietary inclusion levels of sunflower oil cake on the growth performance of South African Mutton Merino lambs. Res. Opinions Anim. Vet. Sci. 1 (5), 330333.

Nkosi, B.D., Vadlani, P.V., Brijwani, K., Nanunja, A. \& Meeske, R., 2012. Effects of bacterial inoculants and an enzyme on the fermentation quality and aerobic stability of ensiled whole crop sweet sorghum. S. Afr. J. Anim. Sci. 42, 232-240.

Oude Elferink, S.J.W.H., Krooneman, J., Gottschal, J.C., Spoestra, S.F., Faber, F. \& Driehuis, F., 2001. Anaerobic conversion of lactic acid to acetic acid and 1,2-propanediol by Lactobacillus buchneri. Appl. Environ. Microbiol. $67,125-132$.

Pryce, J.D., 1969. Modification of the Barker \& Summerson method to determine lactic acid. Analyst 94, $1151-1152$.

Ranjit, N.K., Taylor, C.C. \& Kung Jr., L., 2002. Effects of Lactobacillus buchneri 40788 on the fermentation, aerobic stability and nutritive value of maize silage. Grass Forage Sci. 57, 73-81.

Reich, L.J. \& Kung Jr., L., 2010. Effects of combining Lactobacillus buchneri 40788 with various lactic acid bacteria on the fermentation and aerobic stability of corn silage. Anim. Feed Sci. Technol. 159, 105-109.

Rooke, J.A., Maya, F.M., Amold, J.A. \& Armstrong, D.G., 1988. The chemical composition and nutritive value of grass silages prepared with no additive or with the application of additives containing either Lactobacillus plantarum or formic acid. Grass Forage Sci. 43, 87-102.

Snedecor, G.W. \& Cochran, W.G., 1980. Statistical Methods (7th ed.). Ames: Iowa State University Press. pp. 507.

Suzuki, M. \& Lund, C.W., 1980. Improved gas liquid chromatography for simultaneous determination of volatile fatty acids and lactic acid in silage. J. Agric. Food Chem. 28, 1040-1041. 
Szucs, J.P. \& Avasi, Z., 2005. The effect of lalsil dry inoculant on the aerobic stability of Lucerne silage. Silage Production and Utilization. Proc. of the $\mathrm{XIV}^{\text {th }}$ International Silage Conference. Eds: Park, K.S. \& Stronge, M.D., Belfast, Northern Ireland. pp. 233.

Szucs, J.P., Suli, A., Meszaros, A. \& Avasi, Z., 2011. Biological inoculants in forage conservation. Anim. Sci. Biotechnol. 44, 136-140.

Tobia, C., Villalobos, E., Rojas, A., Soto, H. \& Moore, K.J., 2008. Nutritional value of soybean (Glycine max L. Merr.) silage fermented with molasses and inoculated with Lactobacillus brevis 3. Livestock Research for Rural Development 20. Article No. 106.

Touno, E., Kaneko, M., Uozumi, S., Kawamoto, H. \& Deguchi, S., 2014. Evaluation of feeding value of forage soybean silage as a substitute for wheat bran in sheep. Anim. Sci. J. 85, 46-52.

Vargas-Bello-Perez, E., Mustafa, A.F. \& Seguin, P., 2008. Effects of feeding forage soybean silage on milk production, nutrient digestion, and ruminal fermentation of lactating dairy cows. J. Dairy Sci. 91, 229-235.

Weinberg, Z.G., Ashbell, G., Hen, Y. \& Azreli, A., 1993. The effect of applying lactic acid bacteria at ensiling on the aerobic stability of silages. J. Appl. Bacteriol. 75, 512-518.

Weissbach, F.E. \& Strubelt, C., 2008. Correcting the dry matter content of maize silages as a substrate for biogas production. 63 Landtechnik 2, 82-83.

Wilkinson, J. M., 2005. Silage. Chapter 19: Analysis and Clinical assessment of silage. Chalcombe Publications, UK.

Wilkinson, J.M. \& Davies, D.R., 2012. The aerobic stability of silage: key findings and recent developments. Grass Forage Sci. 68, 1-19.

Woolford, M.K., 1990. The detrimental effects of air on silage. J. Appl. Bacteriol. 68, 101-116.

Xu, Ch., Wang, H., Yang, F. \& Yu, Zh., 2011. Effect of an inoculant and enzymes on fermentation quality and nutritive value of erect milkvetch (Astragalus adsurgens Pall.) silages. J. Anim. Feed Sci. 20, 449-460.

Zhang, X.Q., Jin, Y.M., Zhang, Y.J., Yu, Z. \& Yan, W.H., 2013. Silage quality and preservation of Urtica cannabina ensiled alone and with additive treatment. Grass Forage Sci. 69, 1-10. 